\title{
能動型消音ルーバー構造を持つ筐体開ロ部からの音響放射
}

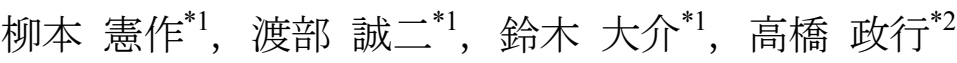

\section{Acoustic radiation at opening with movable louver ANC system}

\author{
Kensaku YANAGIMOTO ${ }^{* 1}$, Seiji WATANABE ${ }^{* 1}$, Daisuke SUZUKI $^{* 1}$ and Masayuki TAKAHASHI ${ }^{* 2}$ \\ ${ }^{* 1}$ National Institute of Technology, Tsuruoka College \\ 104 Sawada, Inooka, Tsuruoka-shi, Yamagata 997-8511, Japan \\ ${ }^{*}$ ORIENTAL MOTOR CO., LTD. \\ 3-4-10 Takarada, Tsuruoka-shi, Yamagata 997-0011 Japan
}

\section{Received 11 August 2015}

\begin{abstract}
This paper describes an active noise control technique to suppress the transmitted sound from a movable louver that is attached to a ventilation aperture and machinery opening. In this experimental study, proposed ANC (Active Noise Control) system is independent parallel control system using two IMC (Internal Model Control) feedback ANC systems. Each system is controlled using filtered-X LMS algorithm to minimize sound pressure at error microphone. One of them, louver-ANC system which secondary noise source is set at each bottom side of the louver vane. An opening of each movable louver vane is one-dimensional space similarly a duct. Transmitted sound is attenuated in this area which error microphone was set on outside near louver opening. The other one is slit-ANC system that is installed on an opening of machinery wall. The slit-ANC system is combined a slit resonator with active noise control. The slit resonator with ventilation aperture composed of thin air layer expanded with very short wall width is useful to reduce leakage noise at machinery wall. The thin air layer acts an acoustic resistance, inertance and capacitance. The secondary noise source oscillates the air layer with appropriate amplitudes and phases. The error microphone is located same position in case of the louver-ANC system. The rectangular slit resonator is designed to reduce resonant frequencies of an enclosure box in this experiment. Noise reduction is visualized by sound intensity measurement system, and sound power is calculated by distribution of sound intensity. The experimental results show that noise reduction is obtained from $5 \mathrm{~dB}$ to $13 \mathrm{~dB}$ of sound power in sound field on this proposed ANC system. And it is expected that the transmission loss of movable louver will be able to improve by using independent parallel control system of louver-ANC and slit-ANC.
\end{abstract}

Key words : Movable louver, Slit resonator, Active noise control, IMC feedback ANC, Filtered-X LMS algorithm, Sound intensity measurement

\section{1. 緒言}

ルーバーは，外枠に細長い羽板を一定間隔・一定角度で並べた換気用装置で，外部からの風雨や塵埃を防ぐた めに空調および換気用の大型ダクト端に多く用いられている.近年, 外観ならびにプライバシー向上の観点から， 外部からの視線を遮って自然換気ができ，遮光と採光も自由に行える開閉型のルーバーが，住宅の空に多く用い られてきている，集合住宅やアパート・マンションの多い日本の住宅事情を考えたとき，空から隣家への生活音 の漏れは，無視することのできない問題である（大内他，2012）。また，このルーバーは防塵ならびに防滴を目的 に機械・機器の冷却用換気口ならびに大型プレス機械の遮音用エンクロージャの通風口に利用されるなどその用 途も広い。これらの機械・機器を設計する上でも, 内部からの放熱・通気, そして遮音といった本来相容れぬ双 方の目的を考慮に入れる必要がある。

本研究に使用した開閉型ルーバーの挿入損失を図 1 に示している.図は，筐体の開口部に設置したルーバーに

No.15-00441 [DOI: 10.1299/transjsme.15-00441], J-STAGE Advance Publication date : 6 January, 2016

*1 正員, 鶴岡工業高等専門学校（广997-8511 山形県鶴岡市井岡字沢田 104）

*2 正員, オリエンタルモーター（株）（广997-0011 山形県鶴岡市宝田 3-4-10）

E-mail of corresponding author:ken@tsuruoka-nct.ac.jp 
おいて，そのルーバー羽板の開口角度のちがいによる挿入損失を示している.ルーバーが完全に閉じた状態，つ まり羽板の開口角度が $0^{\circ}$ では概敉質量則に乗って遮音効果が得られている. しかしルーバーの開口角度が $15^{\circ}$ とわずかに開口しただけで挿入損失は大幅に低下し，1 kHz 以下の低周波数帯においては開口角度によらず遮音 効果がほとんど観られない. 本研究はこのような理由から開閉型ルーバーを持つ筐体開口部における遮音特性の 向上を目的として能動騒音制御（Active noise control, ANC）を行った. 能動騒音制御は, 従来ダクトのような音 波が一次元的に伝播する比較的低周波数領域で有効 (Kido et al., 1989)（小林，藤岡，2006）とされているが，ルー バーによって仕切られた各羽板間を一次元的空間と考えると, 羽板隙間において能動騒音制御を行うことで, 開 閉型ルーバーの遮音性能が向上寸ると考えられる（この方式をルーバー能動消音器と呼ぶ）．著者らは，これまで ルーバーの各羽板に二次音源（制御音源）を取付け，これを筐体開口部に設置した場合の ANCによる消音効果 について，実験的に明らかにした(小泉他，2006)。その結果，制御ポイントにおいて $200 \mathrm{~Hz} \sim 4 \mathrm{kHz}$ の範囲で 15 $\mathrm{dB}$ から $30 \mathrm{~dB}$ の消音量が得られたが，減音領域を広げるための遮音効果が不十分であった.

開口部寸法が波長をはるかに超えた大型開口部の能動騒音制御では, 開口部に複数の仕切り板を挿入すること で開口面積を変化せずに, 無相関な音圧・位相分布を相関のある離散点音源群に改変し実現している（江波戸他, 2003）。このように大型開口部については小型ダクト化することで, 開口部上方で $3 \mathrm{~dB} \sim 10 \mathrm{~dB}$ の音圧低減を達成 している. 音響パワーを最小化するためにより最適な複数の制御点が必要であり, 制御アルゴリズムやシステム の複雑化など実用面から困難な点が多い. 省スペース化が優先される機械·機器などの開口部における通気と遮音 の相容れぬ目的を達成する方法として, 機器壁面に設けたスリット状共鳴器と ANC との複合消音システム（ス リット能動消音器）が報告されている（柳本他，2000）。これによれば, スペースをそれほど必要としない音場境 界面での能動騷音制御により減音領域の拡大が可能である.

そこで本研究は, 開口部でのルーバー能動消音器による遮音効果の拡大を目的に, スリット能動消音器を併用 した消音システムを構築した (図 2)。 また, システムの小規模化を目的に IMC (Internal Model Control) 構成に よる適応フィードバック制御を二系統併用し，それぞれを独立して制御する方式（大西他，2008）を用いた。減 音領域の拡大ならびに制御システムの小規模化を目的とした研究では, 遮音壁についてフィードバック制御によ る音響境界制御の効果とフィードフォワード制御による音圧制御の効果によるハイブリッド ANC で実現している (王他，2014）. 本報告は，ルーバー状開口部から放射される筐体の共鳴音など離散周波数音を制御対象とし, 本 提案システムの有用性を示す目的で消音効果ならびに音響インテンシティ手法により減音領域の可視化を行った. このため実験には，1/3 オクターブバンドの中心周波数，および筐体の共鳴周波数の単一周波数音を一次音源と して用いた. その結果, ルーバー能動消音器にスリット能動消音器を併用した能動型消音ルーバー構造により, 音場境界面での遮音効果を高めることができたので報告する，なお，本実験では筐体内部の冷却を目的としたク ーリングファンなど流れの影響の無い条件で実験を行った.

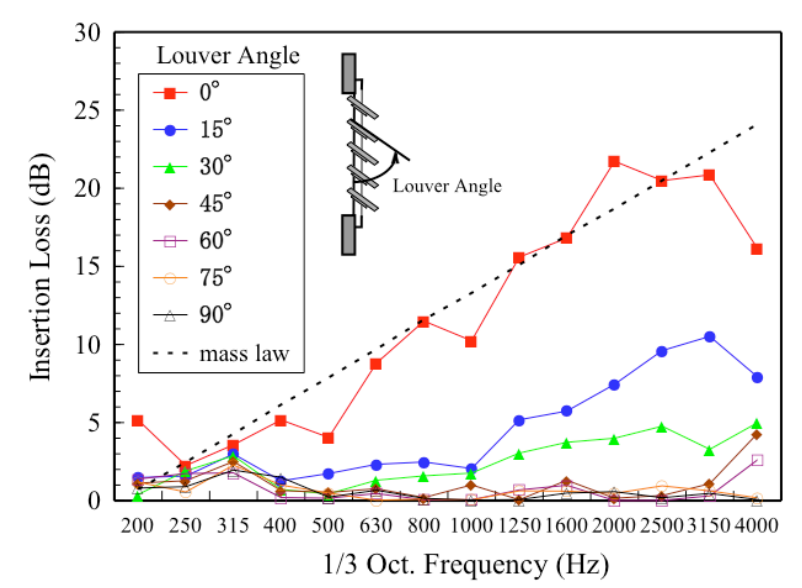

Fig.1 Insertion loss of the movable louver in this experimental study. Mass law (TL) calculated by $m=1.53 \mathrm{~kg} / \mathrm{m}^{2}$ is plotted with the dashed line.

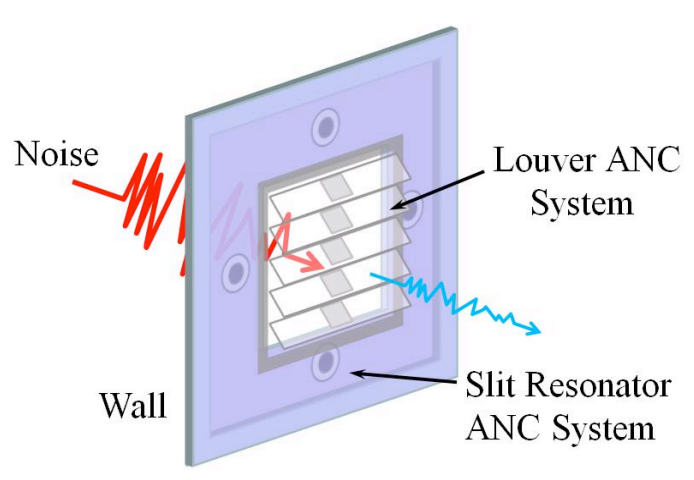

Fig.2 Concept of the movable louver ANC system. The proposed system consists of the louver-ANC system and slit-ANC system. These two ANC systems are parallel driven independently. 


\section{2. 能動型消音ルーバー構造について}

\section{2 - 1 ルーバー能動消音器とスリット能動消音器との併用システム}

能動型消音ルーバー構造の基本的なコンセプトを図 3 に示す.ルーバー能動消音器は，ルーバーに伝搬してく る空気音を能動的に干渉し，入射音を消音することを目的にしている．筐体内部で発生した騒音はルーバーに伝 搬し，その一部は羽板により反射されるが，多くは羽板の隙間を通って外部に伝搬されて行く.これら羽板の隙 間は筐体の外から観るとルーバーに分布する騒音源とみなすことができ，これに近接して制御音源を有した羽板 を配置し消音する.ルーバーによって仕切られた各羽板間を一次元的空間とみなせれば，羽板隙間において制御 音を発生させ，ルーバー羽板間の隙間を伝播するさまざまな空気音に適応して制御音波面を作り消音することが できる。ささらに，ルーバー能動消音器を取付ける筐体の開口部周囲の淵から壁面内には，空気薄膜の持つアドミ タンス特性を利用したスリット状共鳴器が形成されている. スリット状共鳴器は, 機器などの筐体壁面内に開口 部と同心な矩形状の空気薄膜を形成することで，スリット幅が壁厚に比べ十分小さな厚さの寸法を特徵としたリ アクティブ型の音波吸収装置として動作する。このような同心な開口部を持った共鳴器は，分布型の受動消音器 として動作するため音響パワーを最小化するのに大変有効であることが理論的に明らかにされている（本田他， 1997).この反面, 消音目標が低周波数になるほど空気薄膜の持つ容積を大きくする必要があり, デザイン上の制 約が生じる。また，空気薄膜のアドミタンス特性を用いているため，その消音量は周波数選択性に大きく依存す る. スリット能動消音器は，このスリット状共鳴器の持つ分布型の受動消音器としての特性とANCを複合する ことにより，開口部での遮音をアクティブに行うことを目的としている．提案したスリット能動消音器は，スピ 一カーからの制御音により空気薄膜を音響加振する。このとき, 制御スピーカーを中心に内部音圧が高まり，制 御音がスリット開口部から騒音を取り囲むように放射される。制御音の位相は，制御スピーカーの周辺や制御ス ピーカーから近いスリット開口部において騒音とは逆位相となり，制御音と騒音の干渉により消音が実現される (渡部他, 2002).

本実験で提案した能動型消音ルーバー構造は，図 4 に示したように筐体の開口部壁面に形成されたスリット能 動消音器にルーバー能動消音器を取付けた併用システムから構成されている.制御システムの小規模化を目的に,

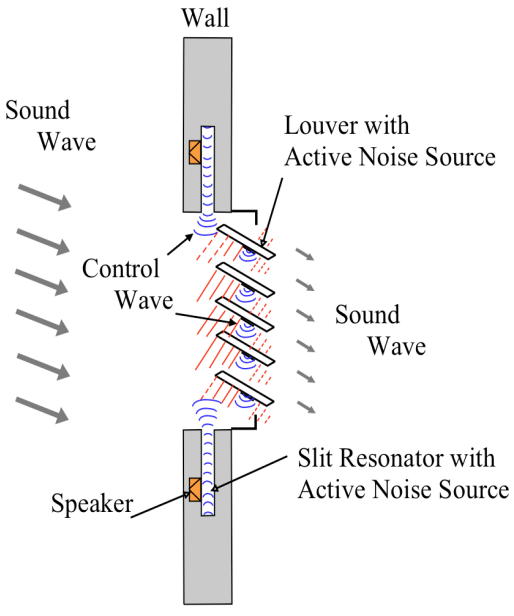

Fig.3 Basic concept of noise reduction by using the movable louver ANC system. A louver combined with slit resonator is attached to a ventilation aperture. Secondary noise sources are set at each vane bottom side and inside of slit resonator.

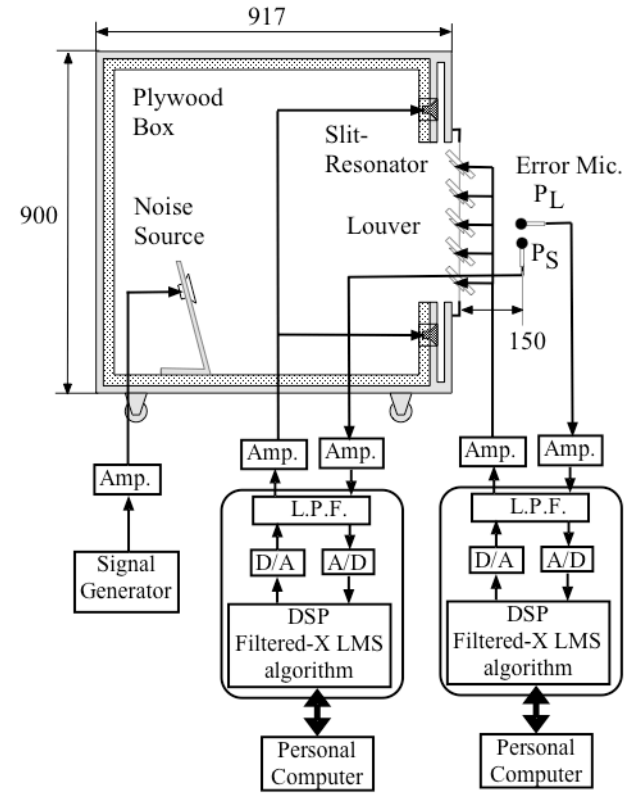

Slit ANC (1-1) Louver ANC (1-1)

Fig.4 Experimental setup. The louver-ANC system and slit-ANC system are driven independently by IMC feedback algorithm. 
1つのセンサーマイクで消音効果の監視と参照信号の推定が可能である IMC 構成の適応フィードバック制御を 採用した．実験には，(1-1）の単チャンネル ANC システムを併用し，ルーバー能動消音器とスリット能動消音器 においてそれぞれ適応フィードバック制御を独立に行う。使用した ANC システムの制御遅延は $0.42 \mathrm{msec}$, 空間 距離 $150 \mathrm{~mm}$ (at $12 \mathrm{kHz}$ ) であり，このためエラーマイクの配置 $P_{L}, P_{S}$ をルーバー開口部の制御音源から $150 \mathrm{~mm}$ の位置としたＩMC 構成の適応フィードバック制御は，設置スペースの観点から優位性が高い反面，空間的時間 遅延が消音量, 周波数帯域に影響することが知られている（加藤他, 2006). 本実験の制御対象がルーバー開口部 から放射される筐体内部の共鳴音などの離散周波数音であることから，一次音源として制御遅延の影響が少ない 単一周波数音を使用した.

\section{$2 \cdot 2$ ルーバー開口部を持つ筐体からの音響放射}

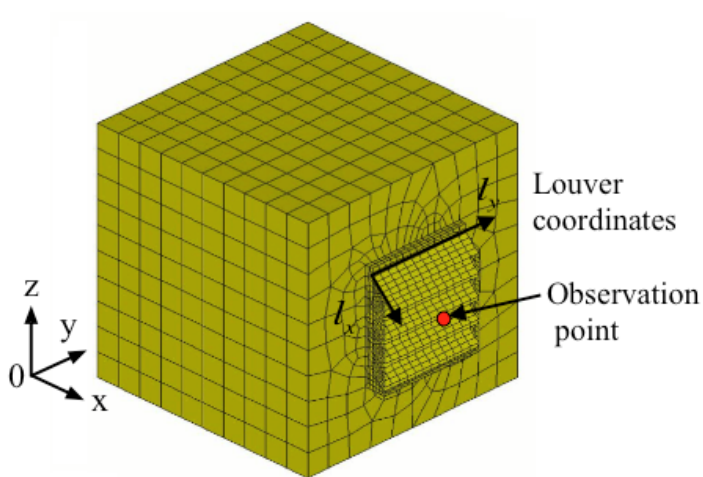

Fig.5 BEM model for the plywood box with louver.

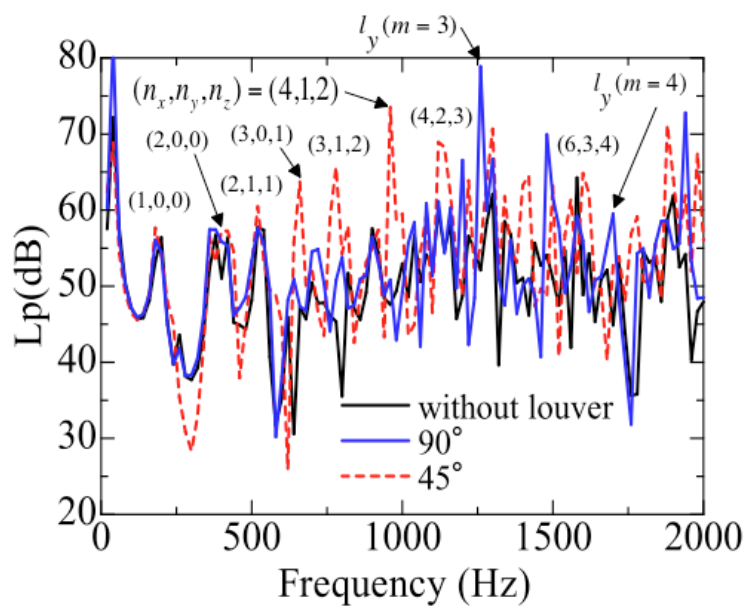

Fig.6 Analysis of sound pressure spectra radiated from the louver. Each peak shows resonant frequency of the inner space of plywood box and opening of louver vane.

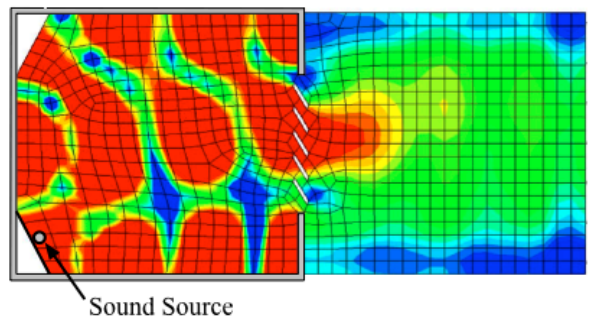

(a) Louver angle $30 \operatorname{deg}(D / \lambda=0.068)$

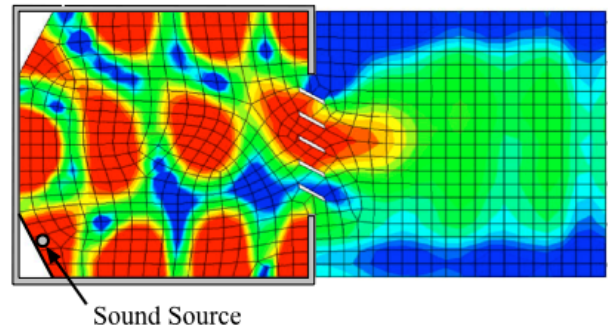

(c) Louver angle $60 \operatorname{deg}(D / \lambda=0.134)$

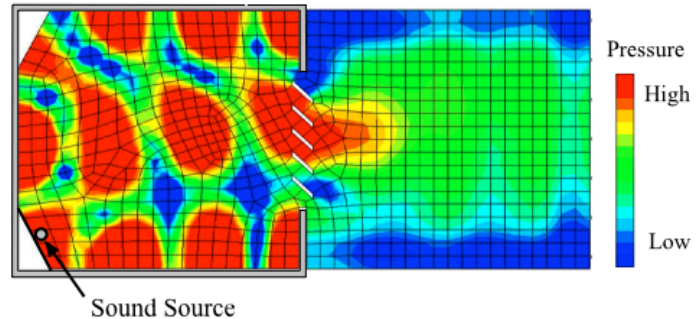

(b) Louver angle $45 \operatorname{deg}(D / \lambda=0.106)$

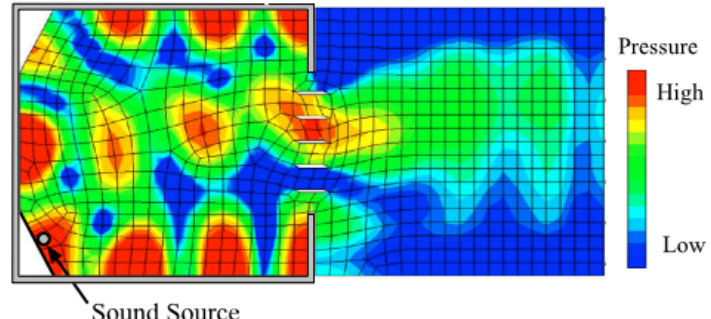

(d) Louver angle $90 \operatorname{deg}(D / \lambda=0.158)$

Fig.7 Calculation of sound pressure contour radiated from the louver on $x-z$ plane (at $y=360 \mathrm{~mm}$ ). Sound source at the $773 \mathrm{~Hz}$ is resonant frequency of the box $\left(n_{x}, n_{y}, n_{z}\right)=(3,1,2)$ mode on the louver angle $45 \mathrm{deg}$. 


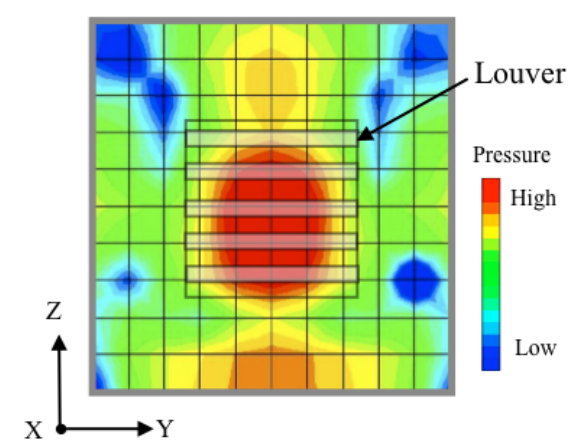

(a) Resonant frequency $773 \mathrm{~Hz}\left(n_{x}, n_{y}, n_{z}\right)=(3,1,2)$

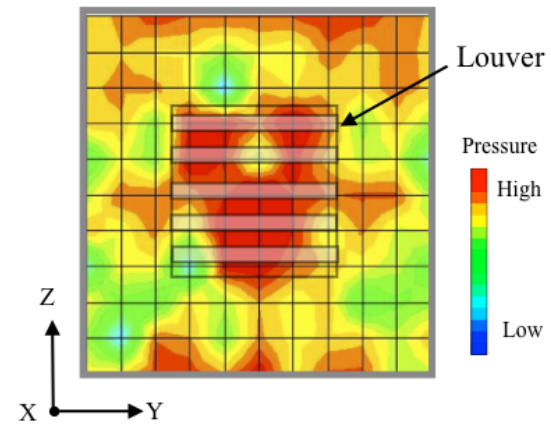

(b) Resonant frequency $1.614 \mathrm{kHz}\left(n_{x}, n_{y}, n_{z}\right)=(6,3,4)$

Fig. 8 Calculation of sound pressure contour radiated from the opening of louver on $y$ - $z$ plane (at $x=1,000 \mathrm{~mm})$ at resonant frequencies $773 \mathrm{~Hz}$ and $1.6 \mathrm{kHz}$ on the louver angle $45 \mathrm{deg}$.

ルーバー状開口部を持った筐体の共鳴周波数ならびにルーバー開口部からの音響放射特性を明らかにするため, 境界要素 法 (BEM) による解析を行った. 図 5 は解析に使用した筐体ならびに開口部に設置したルーバーのBEM モデル（筐体内寸 $820 \mathrm{~mm} \times 820 \mathrm{~mm} \times 820 \mathrm{~mm}$ ，羽板 $80 \mathrm{~mm} \times 425 \mathrm{~mm} \times 10 \mathrm{~mm} ）$ を示している．解析では，筐体内部の音源を点音源として扱 い, 筐体内部の左下の傾斜した壁面上に配置し (図 7 参照), 点音源からの垂線がルーバーの中央で交差する斜入射とした. 筐体外部は自由空間とした．また，観測点はルーバー開口部の中央から $150 \mathrm{~mm}$ ，床上 $535 \mathrm{~mm}$ の位置とした．図 6 にこの 観測点でのルーバー開口部からの放射特性を示す. 直方体の笚体の中の共鳴周波数は, $x, y, z$ 方向の定在波の次数 $n_{x}, n_{y}$, $n_{z}$ の任意の組み合わせによって，不連続に無数あることが知られている. $500 \mathrm{~Hz}$ 以下の周波数域では，ルーバーの有無に 関係なくほとんど開口部からの放射特性は同じである.ルーバーの開口角度が $45^{\circ}$ では, $600 \mathrm{~Hz}$ を越えたあたりからピー クが顕著に現れている．これらは，筐体内部の $x$ 方向にできる定在波の高次なモ一ド数 $\left(n_{x}\right)$ に対応する周波数 $\left(n_{x} n_{y} n_{z}\right)=$ (3,0,1)，(3,1,2)，(4,1,2),(4,2,3)，・・・，である. また，ルーバーを全開した（開口角度 $90^{\circ} ）$ では，1 kHz以下の周波数 域においてその放射特性は，ルーバーの無い開口のみの場合（without louver）とほぼ一致している. しかし約 $1.2 \mathrm{kHz}$ 以上 では, ルーバーの羽板に挟まれた空間の共鳴周波数て顕著なピークが現れている．数值解析の結果，開口角度 $90^{\circ}$ ではル 一バーの羽板に挟まれた空間の $l y$ 方向の共鳴周波数 ( $m$ はモードの次数 $) 404 \mathrm{~Hz}(m=1), 807 \mathrm{~Hz}(m=2), 1255 \mathrm{~Hz}(m=3), 1673 \mathrm{~Hz}$ $(m=4)$ とピーク周波数が一致していた.

図 7 (a),(b)(c),(d)に，ルーバーの開口角度のちがいによる透過音の様子を示す.シミュレーションは筐体の内部音源が共鳴 周波数 $773 \mathrm{~Hz}\left(\left(n_{w}, n_{y}, n_{z}\right)=(3,1,2)\right.$ モ一ド $)$ の場合で，ルーバー開口部からの音響放射を $X-Z$ 面の音圧コンター図で表して いる. ルーバーの羽板間隔 $(D)$ と透過音の波長との比は， $D / \lambda=0.068 \sim 0.158$ の範囲にある. 図 7 (a)のようにルーバー開 口角度が小さいほど定在波により筐体内部の音圧が高まるとともに, ル一バー開口部の放射音圧も大きくなっている. 図 7 (d)に示した開口角度 $90^{\circ}$ では, ルーバー開口部の境界条件が大きく変化し，共鳴周波数が $790 \mathrm{~Hz}$ と高域側にシフトするた め筐体内中央の定在波が弱まるとともに，ルーバー開口部の音圧分布も小さくなっている.

以上のことから, ルーバー状の開口部を持った筐体からの音響放射は, 筐体内部の共鳴による周波数ならびにルーバーの 羽板に挟まれた空間の共鳴周波数で大きくなることが示唆された.

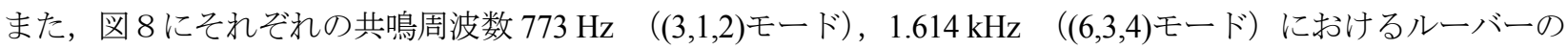
隙間から放射される音圧の分布を示す。これらの共鳴周波数において，筐体内部の y方向伝播の定在波は中央付 近で節となり音圧が小さくなるが，ルーバーの開口部では中心付近の音圧が大きくなっている．これらのことか ら，ルーバー羽板の中央に制御音源を設置することで消音効果が得られると考えられる.

Table 1 Distance of vane interval at each louver angle.

\begin{tabular}{c|c|c|c|c|c|c}
\hline \hline Louver Angle & $15^{\circ}$ & $30^{\circ}$ & $45^{\circ}$ & $60^{\circ}$ & $75^{\circ}$ & $90^{\circ}$ \\
\hline $\begin{array}{c}\text { Vane Distance } \\
D(\mathrm{~mm})\end{array}$ & 10.7 & 30.0 & 46.6 & 59.3 & 67.3 & 70.0 \\
\hline
\end{tabular}




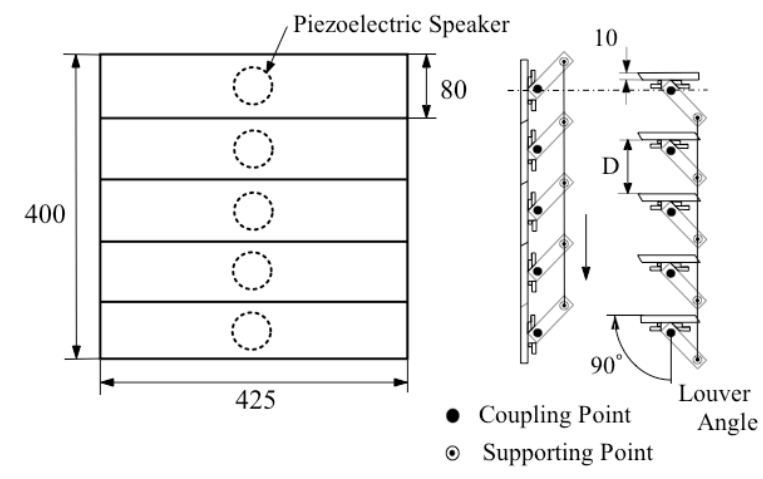

Fig.9 Mechanism of the movable louver. Piezoelectric speakers are attached to the bottom side of each louver vane.
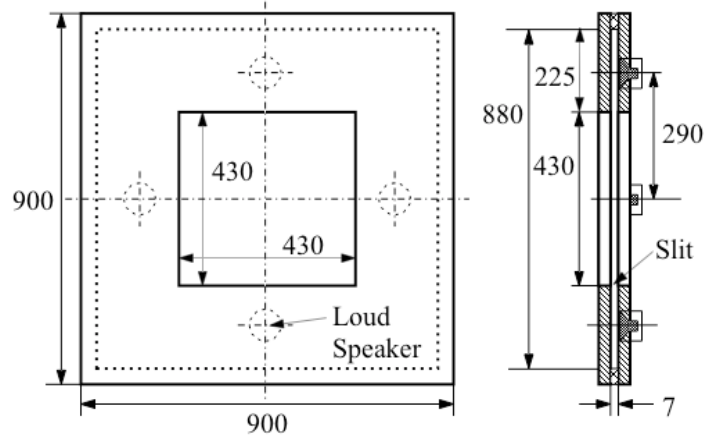

Fig.10 Profile of the rectangular slit resonator. Four loudspeakers are installed in the slit resonator.

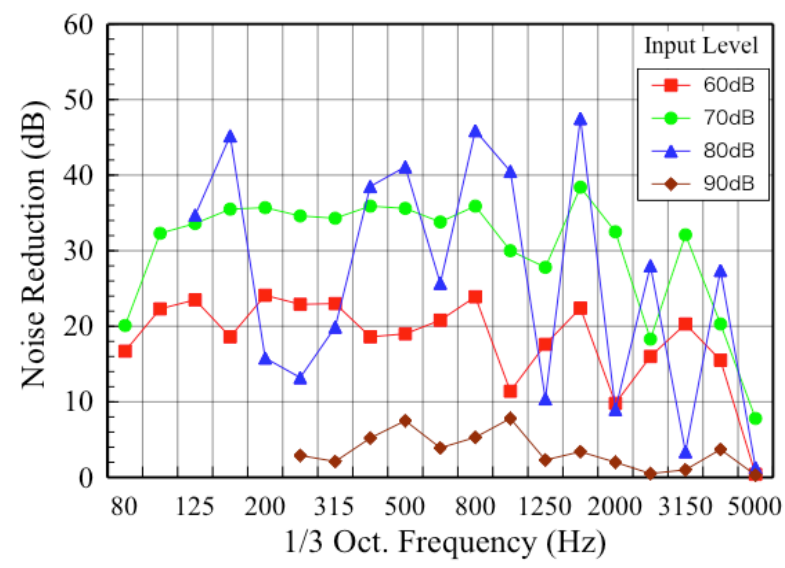

Fig.11 Relation between noise reduction and sound pressure level of primary noise source at control point for the slit-ANC system. Experimental result shows that less noise reduction is obtained over the input sound pressure level of $80 \mathrm{~dB}$.

\section{3. モデル実験および方法}

\section{$3 \cdot 1$ 開閉式ルーバーモデルと ANC システムについて}

本研究では開閉式のルーバーの模型を製作し，これを筐体の開口枠に設置して実験を行った. ルーバーの寸法を図 9 に示 す. 羽板は合板製 $(80 \mathrm{~mm} \times 425 \mathrm{~mm} \times 10 \mathrm{~mm})$ を 5 枚，ルーバーの閉鎖時，羽板間に隙間が生じないように $30^{\circ}$ の面取り が施してある. 各羽板の両端を支持金具にて連結し, 開口角度 $0^{\circ}$ から $90^{\circ}$ まで $15^{\circ}$ 刻みで可動できるようにしている. ルーバーの各開口角度における羽板間距離 $(D \mathrm{~mm})$ を表 1 に示している.ルーバーの羽板裹側の中央には，それぞれ制御 音源として圧電型スピーカー（直径 $63 \mathrm{~mm} \times$ 厚さ $11.5 \mathrm{~mm}$ ，出力 $80 \mathrm{~mW}$ ）を取付けルーバ一能動消音器とした. 実験で は単チャンネル ANC を使用しているため, 各圧電型スピーカーから同振幅・同位相の制御音が放射される.このルーバー 能動消音器は，筐体の前面中央の開口部 $(430 \mathrm{~mm} \times 430 \mathrm{~mm})$ に取付けている. 筐体は外寸 $900 \mathrm{~mm} \times 900 \mathrm{~mm} \times 900 \mathrm{~mm}$, 厚さ $10.5 \mathrm{~mm}$ の合板製 (厚さ $0.5 \mathrm{~mm}$ の鈶シートが貼付) で, 厚さ $30 \mathrm{~mm}$ のグラスウールを内張りした. 騒音源 (一次音源) は，スピーカーの向きが開口部中央になるように筐体内部後方の床面に設置した．騒音は，160 Hzから $5 \mathrm{kHz}$ の範囲で， 1/3 オクターブバンドの中心周波数の正弦波をシグナルジェネレータから出力した.

図 10 にスリット能動消音器を示す. 中心にルーバーを取付けるための通風用の開口を有する外装パネル 2 枚と, これと 同心で幅 $10 \mathrm{~mm} \times$ 厚さ $7 \mathrm{~mm}$ の方形枠のスペーサを外装パネルの周囲にはさみ矩形状の空気薄膜（開口部のスリット幅 7 $\mathrm{mm}$ ，スリット深さ $225 \mathrm{~mm}$ ）を形成している. スピーカーからの制御音によってこの空気薄膜を音響加振することにより，

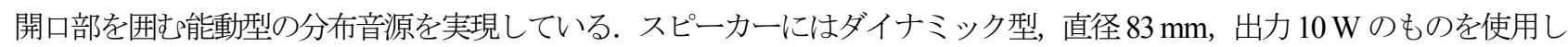
た. 単チャンネル ANC を使用することから, 振幅ならびに位相特性のほぼ等しいもの 4 個を上下左右 $90^{\circ}$ 間隔で外装パネ ルの側面内，開口部中心より $290 \mathrm{~mm}$ に取付けている. このスリット能動消音器は，筐体の前面中央にはめ込んでいる. 
今回設計した矩形状の空気薄膜のアドミタンス特性は, $f_{\mathrm{s}}=213 \mathrm{~Hz}, 473 \mathrm{~Hz}, 620 \mathrm{~Hz}, 780 \mathrm{~Hz}, 1.13 \mathrm{kHz}, 1.51 \mathrm{kHz}, 1.73 \mathrm{kHz}, 1.92$

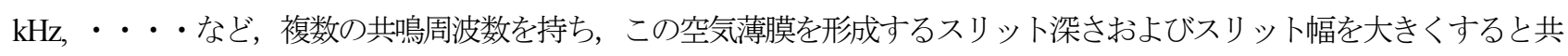

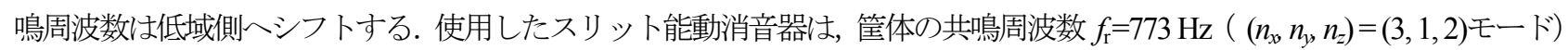
に近い值の共鳴周波数 $f_{\mathrm{s}}=780 \mathrm{~Hz}$ を持っている. またスリット幅は, スリット能動消音器の消音量に影響することが明らか になっている(渡部他，2002). 図 11 に本スリット能動消音器の消音性能を示寸. 図は制御点における入力音圧のレベルを パラメータに，1/3 オクターブバンドの中心周波数の正弦波音に対する消音量を示した. 入力音圧のレベルが $70 \mathrm{~dB}$ では, 周波数 $100 \mathrm{~Hz}$ から $800 \mathrm{~Hz}$ の範囲において，ほぼ暗騒音レベル（35 dB）までに必要な消音量を示している．しかし $80 \mathrm{~dB}$ 以上では, 消音効果が飽和してしまい望まれる消音量が得られないことがわかる.このように十分に消音効果が得られる入 力音压制限があるため, 実験では一次音源からの音圧レベルを $80 \mathrm{~dB}$ 未満とした. また, 音の測定は消音効果を調べるた めに暗騒音レベル $35 \mathrm{~dB}$ 程度の半無響音室で行った.

\section{$3 \cdot 2$ 独立したIMC フィードバック制御方式と実験}

ルーバー能動消音器ならびにスリット能動消音器は, それぞれ独立した IMC 構成の適応フィードバックにより制御され る. 使用した適応アルゴリズムは Filtered-X LMS アルゴリズムである. フィードフォワード制御の参照信号と誤差信号を 1 つのマイクロフォンから得るもので, エラーマイクの配置を二次音源に近接して配置できる. 図 12 にルーバー能動消音器 の適応フィードバック制御のブロック図を $Z$ 表現で表わしている. 図中の $D(z)$ はエラーマイク位置において, 筐体内部に 設置された一次音源からルーバーに伝搬されてきた音を表わす. $C(z)$ および $\hat{C}(z)$ は, それぞれルーバーの羽板に取付けら れた二次音源からエラーマイクまでの二次経路の伝達関数と, これを推定して得られた伝達関数を表わす. 適応フィードバ ック制御では, $\hat{C}(z)$ の出力信号 $\hat{Y}(z)$ とエラーマイクの出力信号 $E(z)$ から $D(z)$ を推測する（渡部他，2005）。

図 12 において, $D(z)$ の推定值 $\hat{D}(z)$ は,

$$
X(z) \equiv \hat{D}(z)=E(z)+\hat{C}(z) U(z)
$$

となる. ここで, $\hat{C}(z)$ が $C(z)$ を十分近似していれば, エラーマイクからの出力信号と二次音源からの出力信号により, 伝搬してくる騒音を予測することが可能となる. 式 (1) を時間領域で表現し直すとフィルタリングした出力信号 $x(n)$ は, 式 (2) となる.

$$
x(n) \equiv \hat{d}(n)=e(n)+\sum_{m=0}^{M} \hat{c} u(n-m)
$$

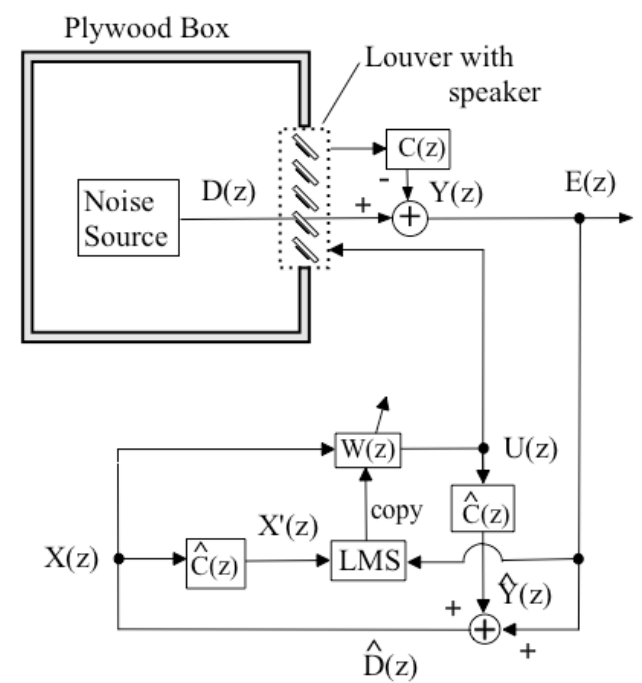

Fig.12 Block diagram of the IMC feedback ANC system for the louver-ANC (1-1).

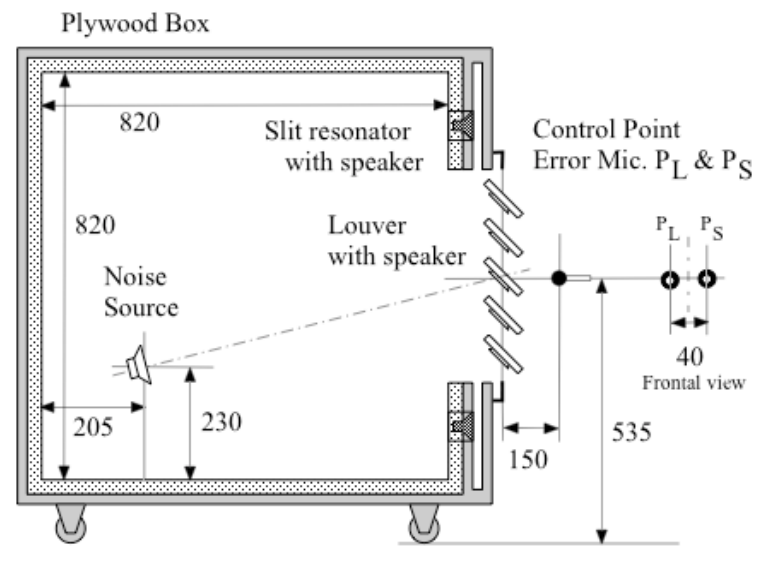

Fig.13 Construction of the parallel ANC system with louver-ANC and slit-ANC. The distance between two error microphones $P_{L}$ and $P_{S}$ is set to $40 \mathrm{~mm}$. 
$\hat{c}$ は, 実際にはオフライン処理により $M$ 次の FIR として同定される. また, 図中のW $(z)$ は FXLMS アルゴリズムにより 同定される次数 $K$ の消音フィルタである. FXLMS アルゴリズムでは, 最終的に式 (3) に基づいてフィルタ係数が逐次更 新されていく.

$$
\begin{array}{r}
\mathcal{W}_{k}(n+1)=\mathcal{W}_{k}(n)+\mu x^{\prime}(n-k) e(n) \\
k=0,1, \cdots, K
\end{array}
$$

ただし， $\mu$ はステップサイズを表わす.

また, スリット能動消音器も同様なアルゴリズムで制御される。この場合の $C(z)$ および $\hat{C}(z)$ は, 矩形薄膜に取付けられ たスピーカーからエラーマイクまでの二次経路の伝達関数と, これを推定して得られた伝達関数を表わす.

実験では，1つのエラーマイクと 1 組の制御用スピーカーからなる単チャンネル ANC を 1 系統としてこれを独立に 2 系 統用いている.ルーバー能動消音器ならびにスリット能動消音器の制御用スピーカーは複数個であるが，ANC の実行中は 各DSP から同一な制御竐号が各スピーカーに送信される. 図 13 にこれらの配置を示す. 本実験ではステップサイズを $\mu=1$ $\times 10^{-6}$, 消音フィルタ $W(z)$ のタップ数を 250 , サンプリング周波数を $24 \mathrm{kHz}$ とした.

ルーバーの各羽板に取付けた制御用スピーカーならびにスリット能動消音器に取付けた制御用スピーカーから制御点で あるエラーマイク $P_{L}, P_{S}$ までの二次経路の伝達特性を図 14(a), (b) に示寸。伝達関数 $\hat{C}(z)$ の測定は, タイム・ストレッチ・ パルス法により測定した. $\hat{C}(z)$ は, タップ数 250 の FIR フィルタとして同定されている. 図 14(a) にルーバー能動消音器 の二次経路の伝達特性を示寸.ルーバーの開口角度が大きくなると $1 \mathrm{kHz}$ 以下のゲインが低下し, $350 \mathrm{~Hz}, 900 \mathrm{~Hz} \sim 1.1 \mathrm{kHz}$ 付近では落ち込みがみられる. また，全開した $90^{\circ}$ では周波数の広域でゲインの低下がみられた。 このようにルーバーの 開口角度の変化により, 羽板間距離や羽板裏側に取付けた二次音源の指向が変化するため, 二次経路の伝達特性への影響が 大きいと考えられる. また, スリット能動消音器の二次経路の伝達特性を図 14(b) に示寸. スリット能動消音器では, 矩形 状空気薄膜の共鳴周波数 $f_{\mathrm{s}}=780 \mathrm{~Hz}$ 付近でピークを示し, $1 \mathrm{kHz}$ 以上でルーバーの開口角度の影響を受けてゲインが変化す る. また, ルーバーの全開 $\left(90^{\circ}\right)$ により周波数の広域でゲインの低下が見られる.ルーバ一能動消音器と比較すると， ルーバーの開口角度による $1 \mathrm{kHz}$ 以下のゲインへの影響は小さい.

\section{$3 \cdot 3$ 併用システムの消音性能とエラーマイクの配置位置の検討}

ルーバー能動消音器とスリット能動消音器はそれぞれ独立して制御されるため, 併用システムの消音性能におよぼす制御 点 (エラーマイク $P_{L}, P_{S}$ の位置) の影響について検討を行った. 図15(a)に示したように, ルーバー能動消音器の ANC シス テムでは, エラーマイクを透過音の音圧レベルの最大付近として, 筐体開口部中央から外に $150 \mathrm{~mm}$ 離れた, ルーバーの左 右中央, 床下より $535 \mathrm{~mm}$ の位置 Louver- $C_{P A}$ に固定して配置した. これに対して, スリット能動消音器のエラーマイクの 位置を, Slit- $C_{P A}$, Slit- $C_{P B}$, Slit- $C_{P C}$ の三力所に配置を変え, 各制御点での消音量を測定した. 制御点 Slit- $C_{P A}$ は, ルーバー能

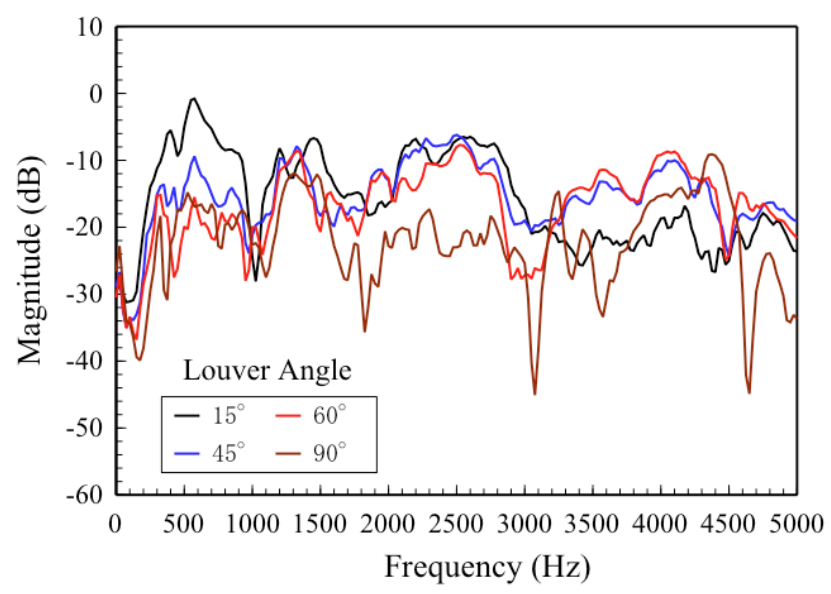

(a) $\hat{C}(z)$ of the louver-ANC system

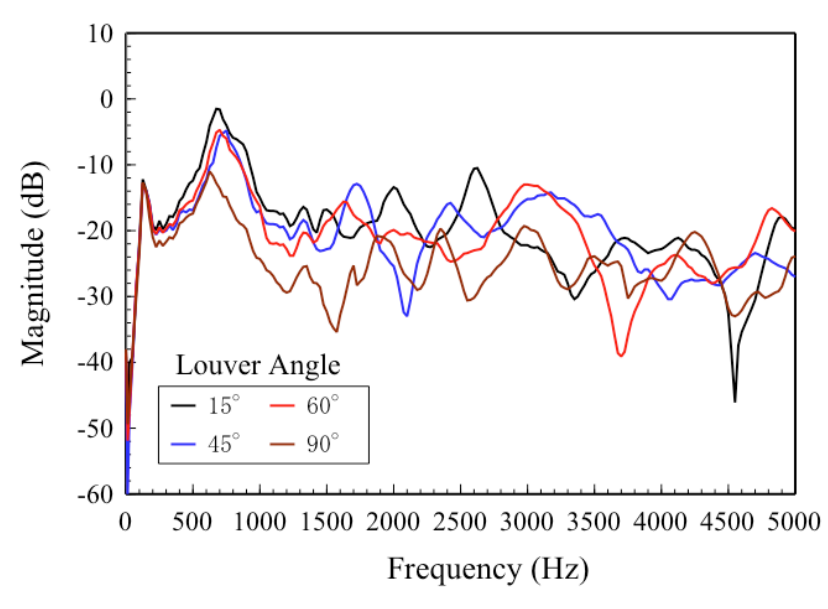

(b) $\hat{C}(z)$ of the slit-ANC system

Fig. 14 Frequency properties of $\hat{C}(z)$. 
動消音器の制御点 Louver- $C_{P A}$ から水平に $100 \mathrm{~mm}$ とスリット側に配置している. Slit- $C_{P B}$ は, 制御点 Louver- $C_{P A}$ から上方 100 $\mathrm{mm}$ の位置である. また, 制御点 Slit- $C_{P C}$ はスリット能動消音器の中央の位置で, これは管路内騒音制御で利用される Tight Coupled Monopole(TMC)の二次音源とエラーマイクの配置を近接したものである. 図 15(b), (c), (d) に，併用システムの制御 点の違いによる消音性能（エラーマイク位置の定点音圧レベルの消音量）を示した. 図 15(b)はルーバー能動消音器および

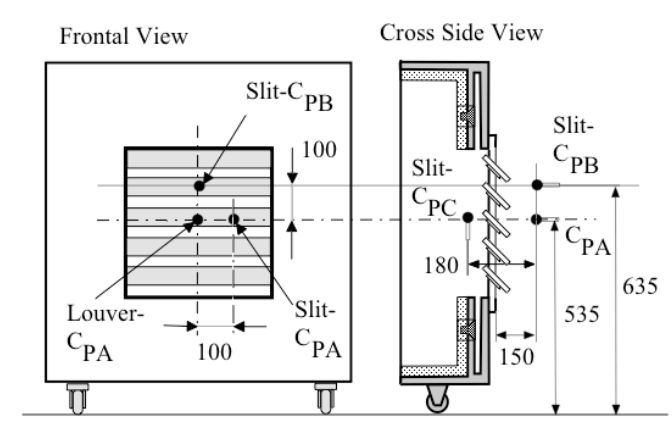

(a) Location of Error Microphone

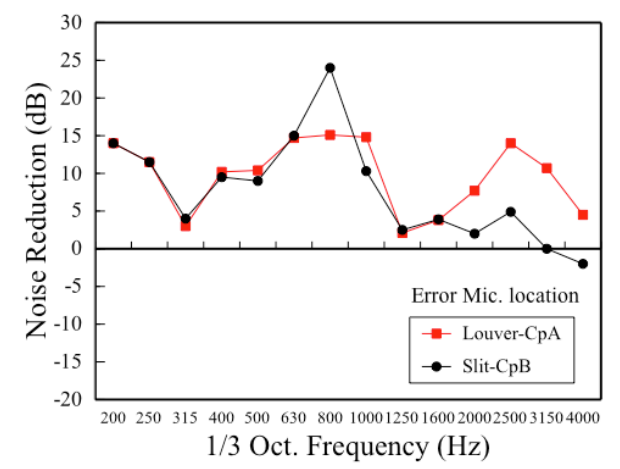

(c) Noise reduction at control point Louver-CPA and Slit-CPB

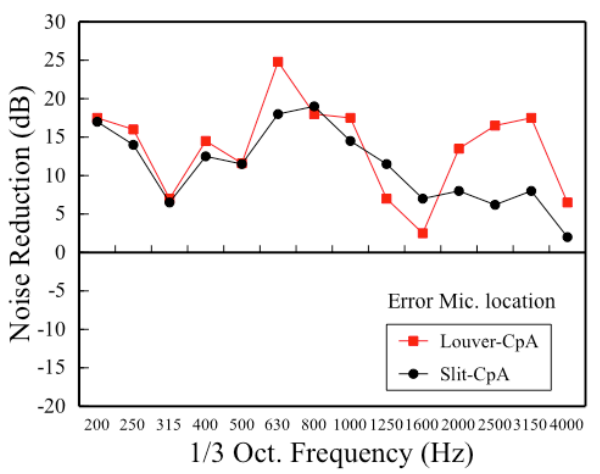

(b) Noise reduction at control point Louver-CPA and Slit-CPA

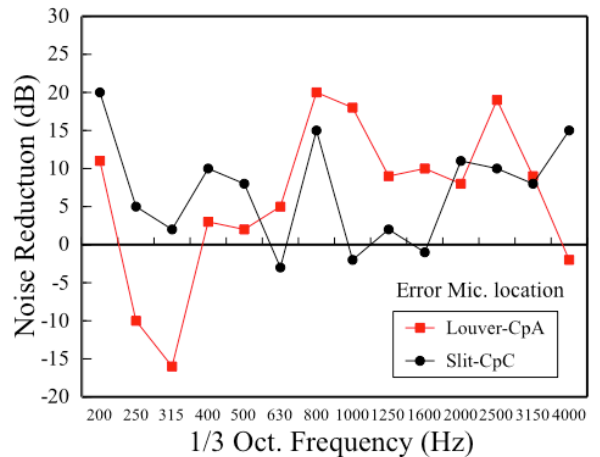

(d) Noise reduction at control point Louver-CPA and Slit-CPC

Fig.15 Comparison of noise reduction at control point for three configurations (location of pair error microphones) on the parallel ANC system. Louver angle is fixed on $45 \mathrm{deg}$. Configuration of control points at Louver- $C_{P A}$ and Slit- $C_{P A}$ as shown in figure (b) performs better.

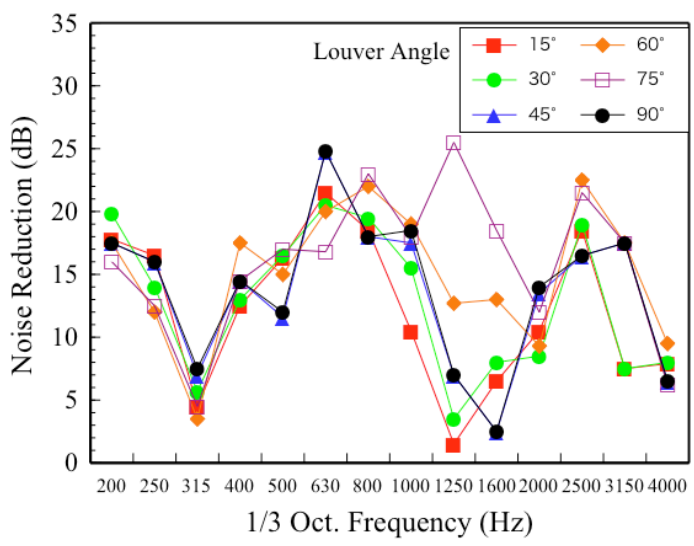

(a) Louver $\mathrm{ANC}$ at control Louver- $C_{P A}$

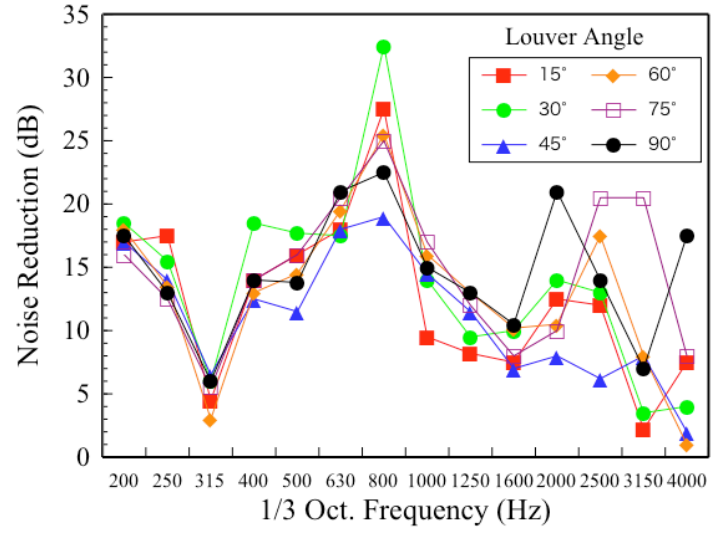

(b) Slit ANC at control Slit- $C_{P A}$

Fig.16 Noise reduction performance at control points for configuration Fig.15(b): Louver- $C_{P A}$ and Slit- $C_{P A}$. At lower frequency $1 \mathrm{kHz}$, noise reduction of the louver-ANC and slit-ANC performs similarly. At the slit-ANC control point, noise reduction can be obtained better at $800 \mathrm{~Hz}$ that is close to the resonant frequency $780 \mathrm{~Hz}$ of rectangular slit. 
スリット能動消音器のエラーマイクを同水平位置（Louver- $C_{P A}$, Slit- $C_{P A}$ ) に配置した場合で，消音量は比較的低域の周波 数 $500 \mathrm{~Hz}$ まではほぼ同じ值を示寸，さらに制御対象音の周波数が高くなり $2 \mathrm{kHz}$ 以上では, 各エラーマイクでの消音量に 差が生じる.これは波長が短くなり, 各制御点におけるルーバ一能動消音器とスリット能動消音器の消音特性の違いが現れ たためと考えられる. 上方に配置した制御点 Slit- $C_{P B}$ の場合でも同様なことがいえるが, 全体的に消音量が小さい. TMC 配置のS Slit- $C_{P C}$ の場合, 消音器の共鳴周波数 $f_{\mathrm{s}}=213 \mathrm{~Hz}, 473 \mathrm{~Hz}, 780 \mathrm{~Hz}, 1.13 \mathrm{kHz}, 1.92 \mathrm{kHz}, \cdots \cdots$ ， に近い 1/3オクターブ 中心周波数では, 比較的消音量が大きくなっている. これに対しルーバ一能動消音器では, 低域の周波数域では増音する. 以上のように，本併用システムの消音性能は，エラーマイクをルーバー中央の開口部へ水平に併設した配置（Louver- $C_{P A}$, Slit- $\left.C_{P A}\right)$ が最適であった.

この最適配置での併用システムにおける各能動消音器の消音性能を図 16(a), (b)に示寸. ANC 制御を実行した前後におけ る制御点での音圧レベルの差を消音量として示している. Louver- $C_{P A}$ 点における入力の音圧レベルは，1/3 オクターブバン ドの中心周波数でほぼ $70 \mathrm{~dB}$ と一定となるようにした. 図 16(a) にルーバー能動消音器のエラーマイク位置 Louver- $C_{P A}$ にお ける消音量を示している. 対象とする一次音源の周波数が $1 \mathrm{kHz}$ 以下の範囲において，ルーバーの各開口角度て概ね $10 \mathrm{~dB}$ $\sim 20 \mathrm{~dB}$ 前後の消音量を得ている. 消音量が少ない $315 \mathrm{~Hz}$ では反共振周波数に近く, 開口部からの放射音のレベルが実験 条件の音圧レベル $70 \mathrm{~dB}$ までに達せず $48 \mathrm{~dB} \sim 55 \mathrm{~dB}$ と低かったことが一要因と考えられる. 図 16(b)はスリット能動消音器 のエラーマイク位置 Slit- $C_{P A}$ の消音量を示している. $1 \mathrm{kHz}$ 以下の周波数域においてはほぼルーバー能動消音器の制御点 Louver- $C_{P A}$ における消音量と同様な值を示している. $1.25 \mathrm{kHz} \sim 1.6 \mathrm{kHz}$ の周波数帯では，ルーバー能動消音器の制御点 Louver- $C_{P A}$ での消音量は少ないが，スリット能動消音器の制御点 Slit- $C_{P A}$ では $10 \mathrm{~dB}$ 前後の消音効果が得られている. また スリット能動消音器では, 特に $800 \mathrm{~Hz}$ 付近の消音量が大きくなっている. これは二次経路の伝達特性が消音器の共鳴周波 数 $f_{\mathrm{s}}=780 \mathrm{~Hz}$ 付近でピークを示し制御音の利得が大きいためと考えられる. $2 \mathrm{kHz}$ 以上の周波数帯では, ルーバーの開口角 度の影響を受けて伝達特性のゲインが変化するため, 消音量も大きく変化している.

\section{4. 音響インテンシティ計測と減音領域の可視化}

\section{$4 \cdot 1$ 実験方法}

実験ではルーバー開口部から透過する音響パワーレベルを音響インテンシテイ法(矢野, 2006)により求め, ANC制御実 行前後での音場の変化を視覚的に考察するとともに，音響パワーレベルの減音量を調ベた. 図 17 に音響インテンシティ計 測のシステム構成を示す．測定は図に示したように，ルーバー開口部に対して水平・垂直な測定領域 $(600 \mathrm{~mm} \times 600 \mathrm{~mm})$ を144 分割 $(12 \times 12)$ し，各分割要素の中心における音響インテンシティレベル（SIレベル）を計測した.

透過音の音響パワーレベルは, ルーバーの透過側に近接して開口面と平行な水平面に測定領域 $(600 \mathrm{~mm} \times 600 \mathrm{~mm})$ を設 け，各分割要素の法線方向の SI レベルから計算した. 音響パワーレベルの減音量 $\Delta P W L$ は, ANC 制御前後における透過 音の音響パワーレベル $P W L[\mathrm{~dB}]$ の差から求めた. 音響パワーレベルの計算は, 測定点の総数 $N=144$, 測定面の 1 升の面
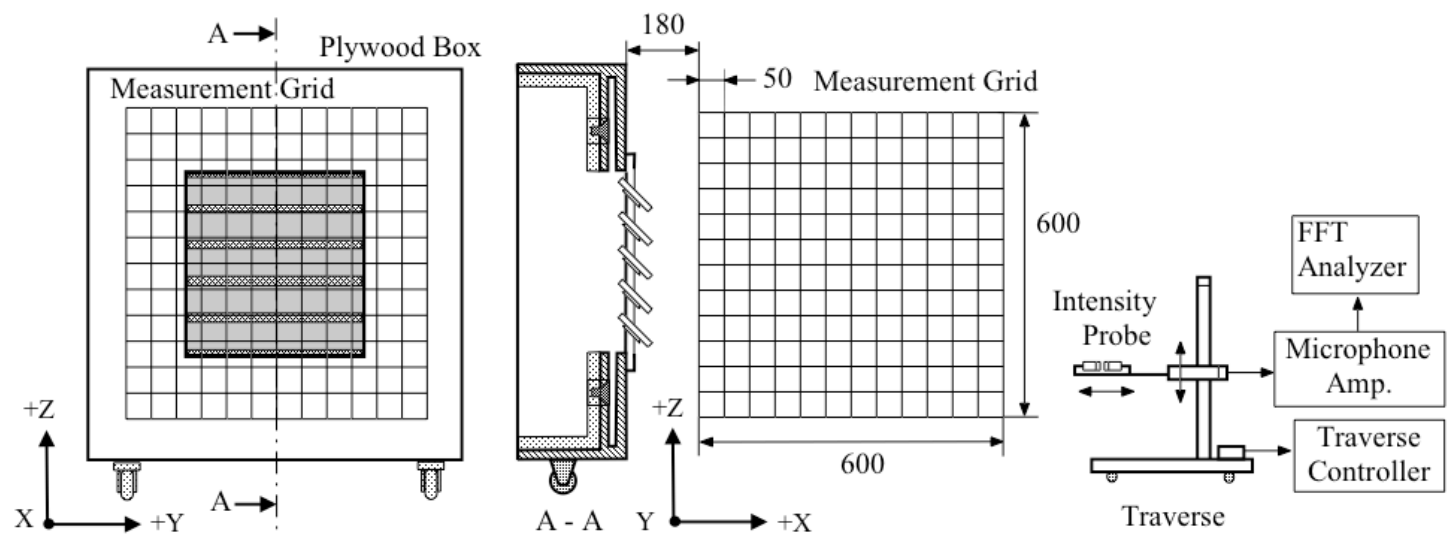

Fig. 17 Constitution of the sound intensity measurement system. The sound intensity is measured on $Y-Z$ plane and on $X-Z$ plane at the center of measurement grids. The sound power level is calculated to substitute Eq. (4) by use of total 144 measurements $I L_{i}$ data on $Y-Z$ plane. 
積 $A=0.0025 \mathrm{~m}^{2}, I L_{i}$ を $i$ 番目の要素の法線方向の $S I$ レベルとして, 次式で計算を行った.

$$
P W L=10 \log _{10}\left(A \cdot \sum_{i=1}^{N} 10^{\frac{I L_{i}}{10}}\right)
$$

\section{$4 \cdot 2$ 測定結果および考察}

スリット能動消音器とルーバー能動消音器をそれぞれ単独動作させた場合, ならびにこの二つを併用動作させ た場合について ANC 制御前後の SI 分布を図 18(a),(b),(c),(d)に表わしている. 図 18(a)は ANC 制御前のルーバー開 口部近傍, $X-Z$ 面の $X$ 方向の $S I$ 分布（ルーバー開口角度 $45^{\circ}, 773 \mathrm{~Hz}$ ）である.この一次音源の周波数は, 筐体 の共鳴周波数 $((3,1,2)$ モード) であり，ルーバー付近で内部音圧が強まり，透過音は上から 2 枚目と 3 枚目の羽 板の隙間を中心としてルーバー正面を同心円状に分布している.これに対して図 18(b)は, ルーバー能動消音器を 動作したときの SI 分布である. ANC 制御後, 透過音は制御点付近で消音され, その減音領域は斜め下方に広が っている，一次音源が開口部の上方に向けた斜入射であること，また単チャンネル ANC を使用しているため制御 点の上方では消音効果が小さいと考えられる. 図 18(c) はスリット能動消音器のみを開口部に設置し, ANC 制御 後の SI 分布を表している. 制御点付近下方では消音するとともに負のインテンシティが分布している. また開口 部の上方でもルーバー能動消音器の場合より $3 \mathrm{~dB}$ ほど消音量が大きい. スリット能動消音器の場合, 筐体の開 口部を取り囲むように音場境界での消音が行われるため, ルーバー開口部から透過して広がる音のエネルギー自 体が小さくなったためであると考えられる，このことからルーバーの開口角度が大きく，音が透過し易い場合で もスリット能動消音器を併用することで減音領域が拡大できることを示唆している.

図 18(d) にルーバー能動消音器にスリット能動消音器を併用動作させた場合のSI 分布を示す. 雨システムの誤 差マイクロフォンは, 図 13 に示したように近接して開口部中央 $P_{L}, P_{S}$ に設置した. 図からわかるように, 併用 動作することで制御点の下方で減音領域が拡大寸るとともに, 開口部上方付近でも消音効果が改善されている.

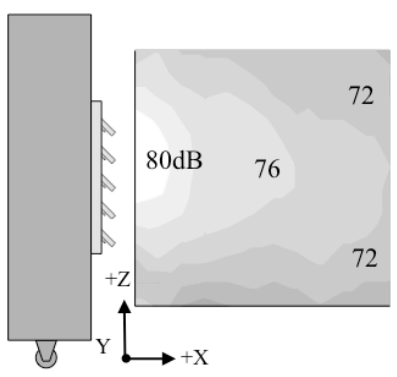

(a) ANC Off

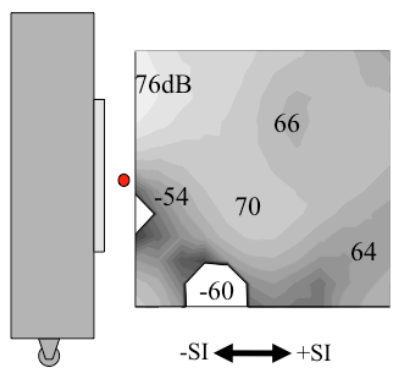

(c) Slit ANC without Louver

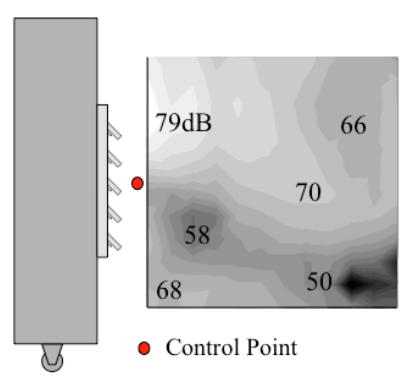

(b) Louver ANC Only

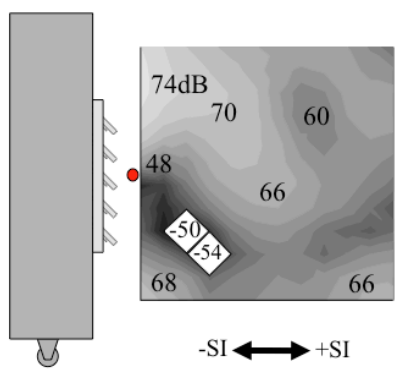

(d) Parallel ANC with Louver and Slit

Fig.18 Comparison of sound intensity level contour map of each louver-ANC, slit-ANC, and both parallel ANC systems. Primary noise source is resonant frequency of box at $773 \mathrm{~Hz}$ on louver angle $45 \mathrm{deg}$. Ratio of louver vane distance for wavelength is $D / \lambda=0.106$. The parallel ANC system with louver-ANC and slit-ANC performs better. Noise attenuation area is broadened for the parallel ANC system. 

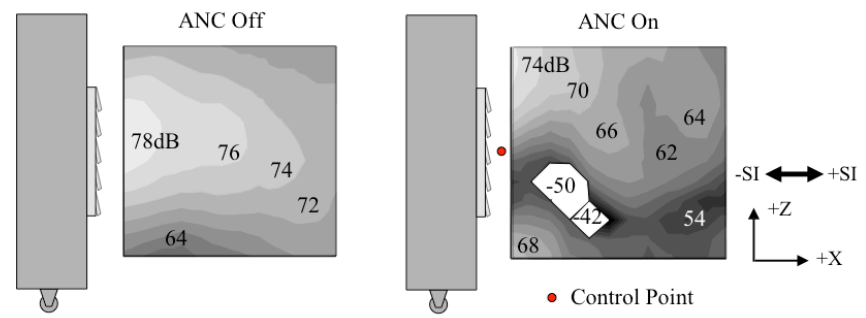

(a) Louver Angle $15 \mathrm{deg}, \mathrm{D} / \lambda=0.024$
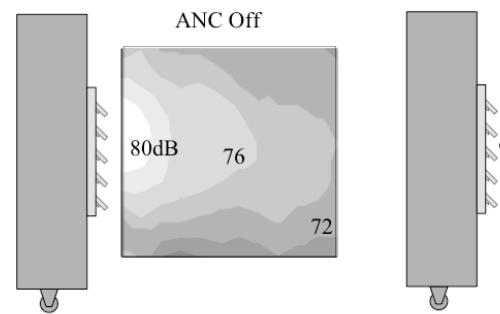

ANC On

(b) Louver Angle $45 \mathrm{deg}, \mathrm{D} / \lambda=0.106$
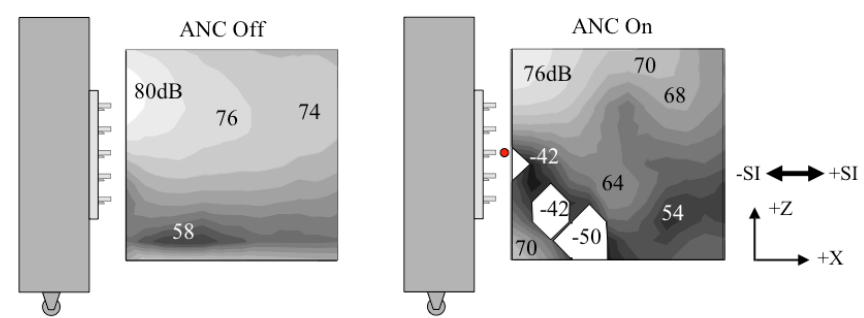

(c) Louver Angle 90deg, $\mathrm{D} / \lambda=0.158$

Fig.19 Contour map of $X$-direction sound intensity level with louver angle change. Primary noise source is sinusoidal signal at the frequency $773 \mathrm{~Hz}$. High sound intensity level tends to distribute upper side of louver opening with louver angle change as shown in figure (c), while ANC system on and off respectively. However, noise attenuation area is broadened at lower space.

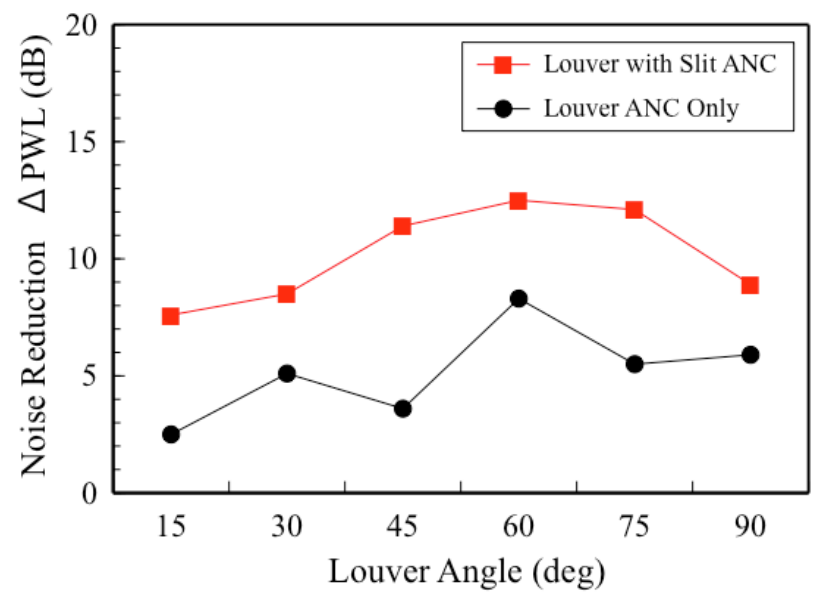

Fig.20 Noise reduction of power level, $\triangle P W L$, by using the parallel ANC system of louver-ANC with slit-ANC. Target is resonant frequency $773 \mathrm{~Hz}$ of plywood box on louver angle $45 \mathrm{deg}$. $\triangle P W L$ is calculated by $P W L$ difference between control on and off. Noise reduction of parallel ANC system performs better than that of single driven by the louver-ANC system. 

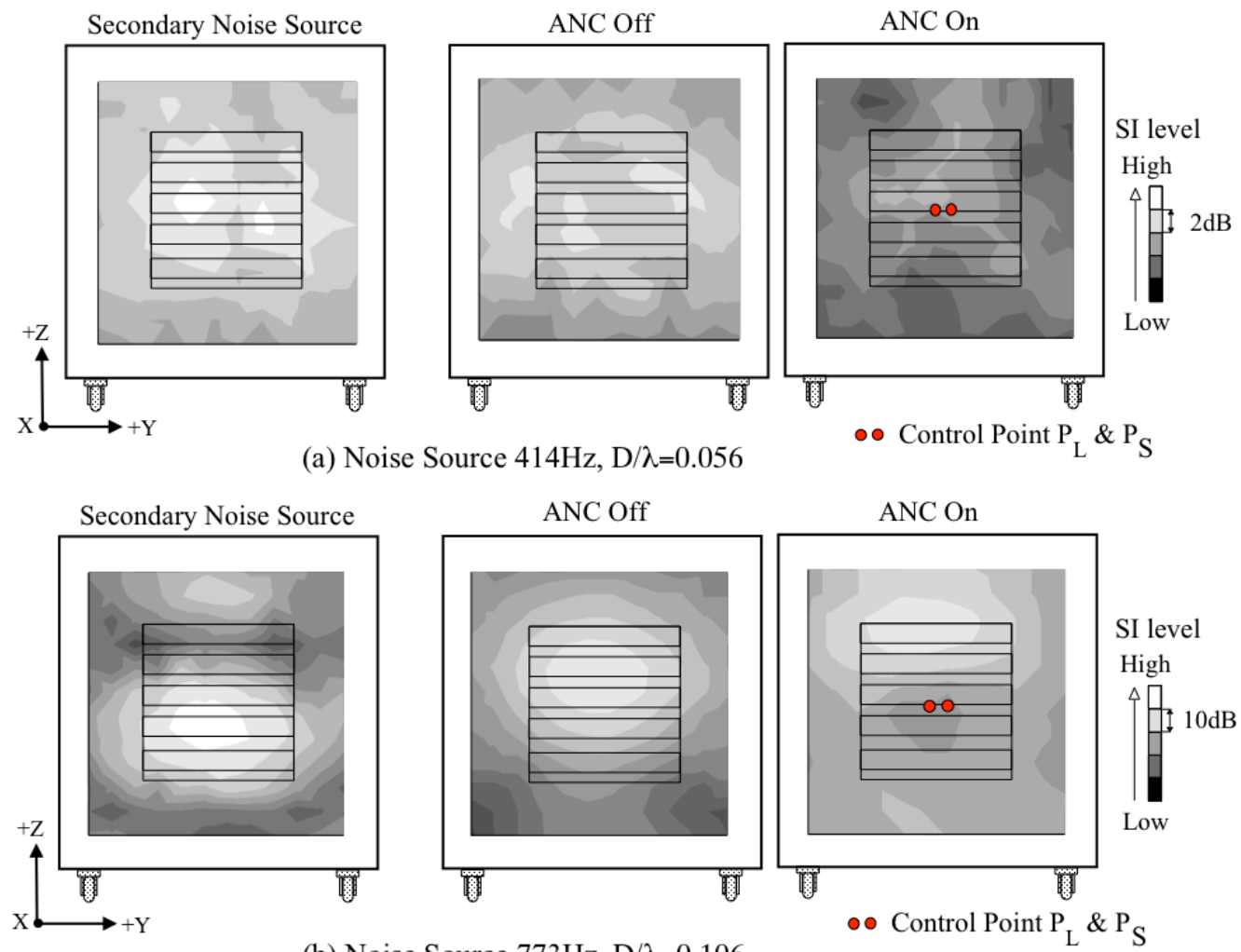

(b) Noise Source $773 \mathrm{~Hz}, \mathrm{D} / \lambda=0.106$
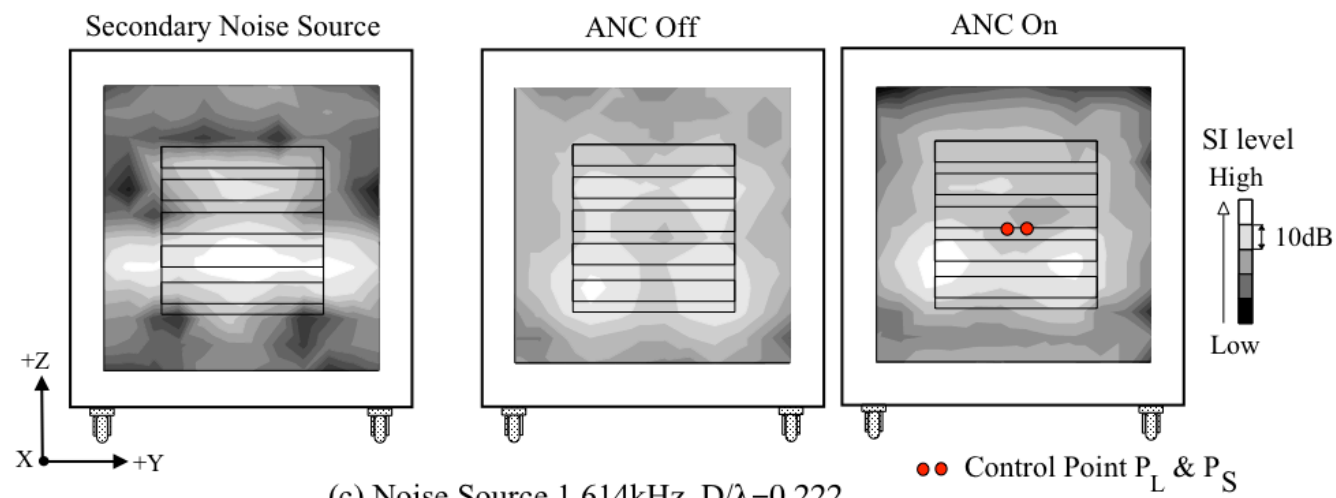

(c) Noise Source $1.614 \mathrm{kHz}, \mathrm{D} / \lambda=0.222$
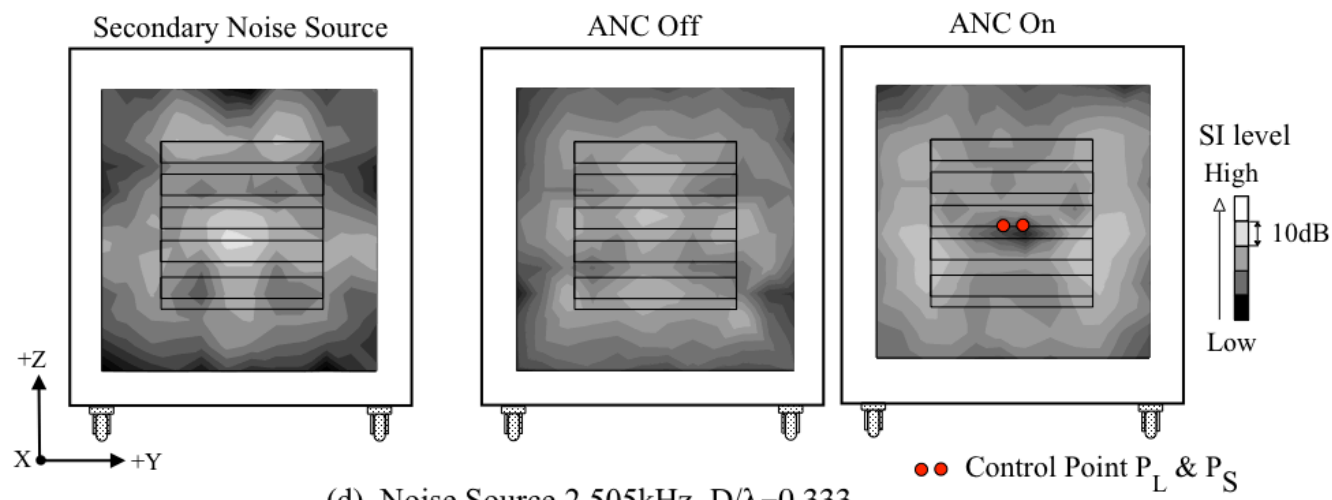

(d) Noise Source $2.505 \mathrm{kHz}, \mathrm{D} / \lambda=0.333$

Fig.21 Sound intensity level contour radiated from the louver opening on $y-z$ plane (at $x=1,000 \mathrm{~mm}$ ). Contour map shows the secondary noise source, active noise control system on and off, respectively. Target frequency is resonant frequencies $414 \mathrm{~Hz}$, $773 \mathrm{~Hz}, 1.614 \mathrm{kHz}$ and $2.505 \mathrm{kHz}$ of plywood box on louver angle $45 \mathrm{deg}$. High level of sound intensity is distributed the center of louver at these resonant frequencies, so the parallel ANC system behaves effectively at configuration of control points $P_{L} \& P_{S}$. 
ルーバーの開口角度が $15^{\circ}, 45^{\circ}, 90^{\circ}$ における制御前後の SI 分布を, 図 19(a),(b),(c) に示す.ルーバーの開口角度が大き くなるにつれて，一次音源の上方に向けての斜入射のため SI レベルの最大位置は徐々に上方に移動する．ルーバーが全開 寸る開口角度 $90^{\circ}$ でも制御点下方で広範囲に減音領域が形成されている. また，開口角度が $15^{\circ}$ から大きくなるにしたが い，制御点のSI レベルは小さくなり，90 では強い負のインテンシティの分布が観察された.

図 20 は, このルーバー能動消音器とスリット能動消音器の併用システムによるルーバーの各開口角度に対する減音量を 示したものである. 筐体の開口部に水平な測定領域における音響パワーレベル $(P W L)$ を式(4)より計算した. 減音量はANC 制御前後の $P W L$ の差から算出している. 減音量はルーバーの開口にともない増加する傾向を示し, 特に開口角度が $45^{\circ} \sim$ $75^{\circ}$ で大きい. 比較のために, ルーバー能動消音器だけを動作させた場合の減音量も示している. スリット能動消音器と の併用により透過音のパワーレベルは概ね $3 \mathrm{~dB} \sim 9 \mathrm{~dB}$ ほど咸音量が増加する.

図 21(a),(b),(c),(d)に，筐体内部に定在波ができる共鳴周波数における ANC 制御前後の SI 分布ならびに，二次音 源の SI 分布を示した. 共鳴周波数 $414 \mathrm{~Hz}((2,0,0)$ モード) では, 開口部にてその透過音はレベル差の少ない平坦 な SI 分布を示している．共鳴周波数 $773 \mathrm{~Hz}((3,1,2)$ モード) では，ルーバー付近で内部音圧が強まり，透過音は 上から 2 枚目と 3 枚目の羽板の隙間を中心としてルーバー正面を同心円状に分布している. 制御音である二次音 源はルーバーの羽板の隙間長手方向に広がる楕円の同心状に分布している. 一次音源の透過音に対してやや下方 に強度中心が位置しているため, 制御時における SI 分布は制御点の下方において減音領域が広く, 上方に $S I$ の 強い分布がある. 高次モードの共鳴周波数, $1.614 \mathrm{kHz}((6,3,4)$ モード $), 2.505 \mathrm{kHz}((7,7,7)$ モード) では, 開口 部に形成される透過音の $S I$ 分布および二次音源の $S I$ 分布のノード数が多くなる. どちらの共鳴周波数でも制御 点付近の音圧が高く, 制御後では開口部における音響パワーは概ね減少する.

図 22 は, ルーバ一能動消音器とスリット能動消音器の併用システムにより, 一次音源の対象周波数 (開口角度 $45^{\circ}$ にお ける筐体の共鳴周波数）を変化させたときの音響パワーの減音量である. 対象とする周波数が高くなるほど ANCによる減 音量は小さくなる傾向にあるが，ルーバー開口部からの透過音のパワーレベルは概ね $5 \mathrm{~dB} \sim 13 \mathrm{~dB}$ ほど減少する.

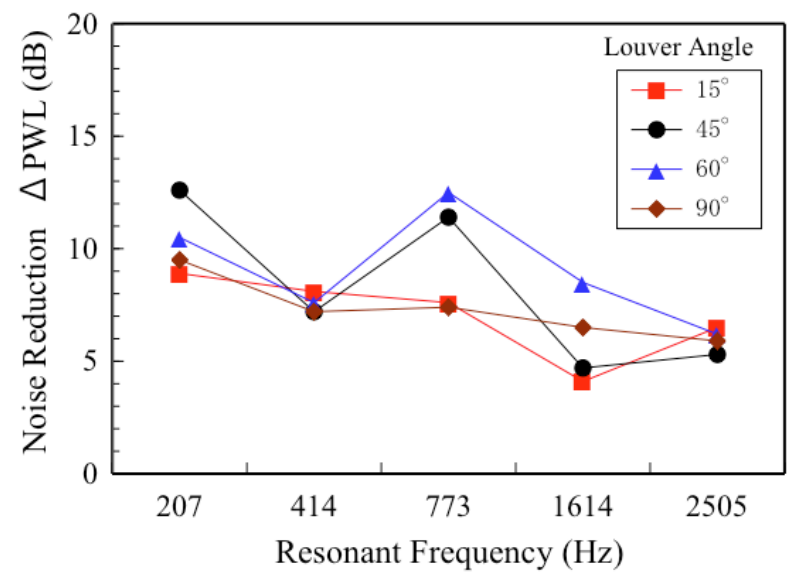

Fig.22 Noise reduction of power level, $\triangle P W L$, for the parallel ANC system of louver-ANC and slit-ANC with primary noise source frequency change. Target frequencies are resonant frequency of plywood box on the louver angle 45 deg. Noise reduction $\triangle P W L$ tends to decrease with frequency. However, noise reduction can be obtained between $5 \mathrm{~dB}$ and $13 \mathrm{~dB}$.

\section{5. 結 言}

本研究は, 開閉型のルーバーを持つ筐体開口部における遮音性能の向上を目的に, IMC 構成による適応フィードバック 制御により,ルーバー能動消音器とスリット能動消音器をそれぞれ独立併用した能動型消音ルーバー構造を構築し, 設計の 指標を明らかにした. さらに本提案のシステムの消音性能を，音響インテンシティ法により可視化するとともに，音響パワ ーレベルの減音量から考察した。

ルーバー状の開口部を持った筐体からの音響放射は, 筐体内部の共鳴による周波数ならびにルーバーの羽板に挟まれた空 間の共鳴周波数で大きくなることが数值解析から示唆された.このためルーバーによって仕切られた各羽板間を二次元的空 
間と考え，羽板隙間において能動騒音制御を行うルーバ一能動消音器では，ルーバーの開口角度が $15^{\circ} \sim 90^{\circ}$ ，対象周波 数 $773 \mathrm{~Hz}$ において $2.5 \mathrm{~dB} \sim 8.2 \mathrm{~dB}$ ほどの音響パワーレベルの減音量が得られた. 開口部壁面内に設けた矩形状の空気薄膜 をスピーカーで音響加振することにより，開口部を囲む能動型の分布音源を実現したスリット能動消音器では, ルーバー開 口部から透過して広がる音のエネルギーが小さくなっているのが音響インテンシテイ計測により観察された.

これら, ルーバー能動消音器とスリット能動消音器をそれぞれ独立して並列動作させたとき, さらに音場における減音領 域は広範囲に拡大した. その結果, 減音量はルーバ一の開口にともない増加し, 特に開口角度が $45^{\circ} \sim 75^{\circ}$ で大きくなる 傾向を示した. ルーバー能動消音器単独の場合と比較して, スリット能動消音器の併用により透過音のパワーレベルは概ね $3 \mathrm{~dB} \sim 9 \mathrm{~dB}$ ほど減音量が増加した. 一次音源の対象周波数（筐体の共鳴周波数）が高くなるほじ本 ANC システムの減音量 は小さくなる傾向にあるが，ルーバー開口部からの透過音のパワーレベルは概ね $5 \mathrm{~dB} \sim 13 \mathrm{~dB}$ ほど減少する.

以上のことから, 本報告で提案したルーバ一能動消音器とスリット能動消音器をそれぞれ独立併用した能動型消音ルーバ 一構造を用いた ANC を行うことで，開閉型のルーバー開口部を持つ筐体で遮音特性の向上が可能と考えられる.

本研究の一部は，公益財団法人 LIXIL 住生活財団（2011）研究助成を受けて行われたことを記し，ここに深く感謝の意 を表す。

\section{文献}

江波戸明彦，田中信雄，永田寿一，穂坂倫佳，塩山 勉，中川 篤，小林雅彦，谷村 新，音響パワーを最小とする能動騒 音制御の研究 (大型開口部放射音の低减手法の提案と実機への応用)，日本機械学会論文集 C 編, Vol.69, No.686 (2003), pp.2541-2549.

本田善久, 大田順一, 松久寬, 受動形消音器による自由音場に放射される音響パワーの低減, 日本機械学会 VS Tech '97 振 動・音響新技術シンポジウム講演論文集, No.97-37 (1997), pp.79-82.

加藤眞司, 飯田裕, 大高慎一, 中澤満, 騒音のフィードバック適応制御に関寸る考察, 日本機械学会 the Dynamics and Design Conference 2006 CD-ROM 論文集, No.06-7 (2006), No.704.

Kido, K., Kanai, H. and Abe, M., Active Reduction of Noise by Additional Noise Source and Its Limit, Transactions of the ASME Journal of Vibration, Acoustics, Stress, and Reliability in Design, Vol.111 (1989), pp.480-485.

小林泰秀, 藤岡久也, 音響ダクトに対する能動騒音制御系の低コストな実装と計画換気システムへの応用, 日本機械学会論 文集 C 編,Vol.72,No.724(2006), pp.3751-3758.

小泉寛也，柳本憲作，高橋政行，渡部誠二，坂本秀一，ルーバーを持った開口部での能動消音に関する研究，日本機械学会 the Dynamics and Design Conference 2006 CD-ROM 論文集, No.06-7 (2006), No.732.

大西慶三，金森直希，西村正治，固定音源・移動音源からの空間伝搬騒音を低減する単チャンネル制御装置を組み合わせた 能動騒音制御手法，日本音響学会誌，Vol.64, No.3 (2008), pp.131-141.

大内孝子, 佐久翔一, 今井章久, スリーブ内の空洞による自然換気口の遮音性能の改善, 日本音響学会誌, Vol.68, No.9(2012), pp.455-460.

王循，木庭洋介，石川諭，雉本信哉，ハイブリッド ANC システムを用いた能動的遮音壁，日本機械学会論文集，Vol.80， No.814(2014), DOI: 10.1299/transjsme.2014dr0165.

渡部誠二, 柳本憲作, 谷藤克也, 坂本秀一, 伊藤孝宏, 一宮亮一, 円形空気薄膜層を壁面内に有寸る機械開口部からの音響 放射（能動型分布音源による消音特性），日本機械学会論文集 C 編，Vol.68, No.674 (2002),pp.282-289.

渡部誠二, 柳本憲作, 谷藤克也, 坂本秀一, 高橋政行, 一宮亮一, 適応フィードバック能動騒音制御による離散周波数音の

抑制，日本機械学会論文集 C 編，Vol.71, No.701 (2005), pp.327-334.

柳本憲作, 伊藤孝宏, 一宮亮一, 円形空気薄膜層を壁面内に有寸る機械開口部からの音響放射 (離散周波数音の減音効果に つい），日本機械学会論文集 C 編，Vol.66, No.646 (2000),pp.345-351.

矢野博夫，インテンシティ法による遮音性能測定と関連 JS 規格，騒音制御，Vol.30, No.3(2006) pp.205-208.

\section{References}

Enamito, A., Tnaka, N., Nagata, T., Hosaka, R., Shioyama, T., Nakagawa, A., Kobayashi, M. and Tanimura, A., A study on active noise control for minimizing total acoustic power (Proposal of sound pressure attenuation method for noise radiated from large duct 
opening and application to the large duct system of transformer), Transactions of the Japan Society of Mechanical Engineers, Series C, Vol.69, No.686 (2003), pp.2541-2549 (in Japanese).

Honda, Y., Ohta, Y. and Matsuhisa, H., Reduction of sound power radiated into free field by passive silencers, Proceedings of the VS Tech '97 Symposium on New Technology of Vibration and Sound of the Japan Society of Mechanical Engineers No.97-37 (1997), pp.79-82 (in Japanese).

Kato, S., Iida, H., Oodaka, S and Nakazawa, M., A consideration about feedback adaptive noise control, Proceedings of the Dynamics and Design Conference 2006 of the Japan Society of Mechanical Engineers No.06-7 (2006), No.704 (in Japanese).

Kido, K., Kanai, H. and Abe, M., Active reduction of noise by additional noise source and its limit, Transaction s of the ASME Journal of Vibration, Acoustics, Stress, and Reliability in Design, Vol.111 (1989), pp.480-485.

Kobayashi, Y. and Fujioka, H., Inexpensive implementation of active noise control systems for acoustic duct with application to a ventilation system, Transactions of the Japan Society of Mechanical Engineers, Series C, Vol.72, No.724 (2006), pp.3751-3758 (in Japanese).

Koizumi, H., Yanagimoto, K., Takahashi, M., Watanabe, S. and Sakamoto, S., A study of active noise control at the opening with a louver, Proceedings of the Dynamics and Design Conference 2006 of the Japan Society of Mechanical Engineers No.06-7 (2006), No.732 (in Japanese).

Ohnishi, K., Kanamori, N. and Nishimura, M., Active noise control method to reduce free field noise from fixed and moving noise source using plural single-channel controllers, The Journal of the Acoustical Society of Japan, Vol.64, No.3 (2008), pp.131-141 (in Japanese).

Ouchi, T., Sakyu, S. and Imai, A., Improvement in the sound insulation of small openings used for natural ventilation by installation of cavity in the sleeve, The Journal of the Acoustical Society of Japan, Vol.68, No.9 (2012), pp.455-460 (in Japanese).

Wang, X., Koba, Y., Ishikawa, S. and Kijimoto, S., A noise barrier using hybrid ANC system, Transactions of the JSME (in Japanese), Vol.80, No.814 (2014), DOI: 10.1299/transjsme.2014dr0165.

Watanabe, S., Yanagimoto, K., Tanifuji, K., Sakamoto, S., Ito, T. and Ichimiya, R., Sound radiation from ventilation aperture with circular thin air layer setting up machinery wall (Noise attenuation by using active noise sources), Transactions of the Japan Society of Mechanical Engineers, Series C, Vol.68, No.674 (2002), pp.282-289 (in Japanese).

Watanabe, S., Yanagimoto, K., Tanifuji, K., Sakamoto, S., Takahashi, M. and Ichimiya, R., Attenuation effects of discrete tone using adaptive feedback active noise control, Transactions of the Japan Society of Mechanical Engineers, Series C, Vol.71, No.701 (2005), pp.327-334 (in Japanese).

Yanagimoto, K., Ito, T. and Ichimiya, R., Sound radiation from ventilation aperture with circular thin air layer setting up machinery wall (Attenuation of DFN radiated from axial flow fan), Transactions of the Japan Society of Mechanical Engineers, Series C, Vol.66, No.646 (2000), pp.345-351 (in Japanese).

Yano, H., Standardization of measurement of sound insulation in buildings and building elements using sound intensity technique, The Journal of the INCE of Japan, Vol.30, No.3 (2006) pp.205-208 (in Japanese). 